\title{
GPS INVESTIgATIONS UNDER CONSTITUTION OF JAPAN - COMPARISON WITH THE U.S CASES
}

\author{
Yuichiro Tsuji \\ University of Tsukuba, Japan \\ tsuji.yuichiro.gm@u.tsukuba.ac.jp
}

TSUJI, Yuichiro GPS Investigations under Constitution of Japan - Comparison with the U.S Cases. International and Comparative Law Review, 2018, vol. 18, no. 1, pp. 179-197. DOI: 10.2478/iclr-2018-0031.

\begin{abstract}
Summary: This paper reviews GPS investigations in Japan and the United States. In 2017, the Japanese Supreme Court held that warrantless GPS search was illegal. The case reviewed in this article illustrates the boundary of permissible investigation using advanced technology and highlights the fact that rapidly developing technology challenges legal research. In the 2017 decision discussed in this paper, law enforcement challenged the permissible scope of investigating warrantless GPS searches; a challenge common in other countries, like the U.S. The U.S. Supreme Court has already decided this case in United States v. Jones decision in 2012. Both of Japanese and American decision takes similar reasoning for their decisions.
\end{abstract}

Keywords: Japan, GPS, search, warrant, privacy, constitution, technology

\section{Introduction}

The Japanese Constitution ${ }^{1}$ has no term for "privacy," in fact, both the notion and scope of "privacy" have been questioned in Japan. The investigative procedure in criminal law is based on the due process of $\operatorname{law}^{2}$ in the Japanese Constitution. The procedure for investigations in criminal matters is based on the due process of law in the Japanese Constitution. Aspect of this due process is guided by Japanese criminal procedure ${ }^{3}$, which contains provisions on criminal investigation involving physical intrusions, such as arrests or searches. However, GPS investigations are not encompassed by the provisions on physical intrusions. In fact, there are no provisions in criminal procedure that address GPS search warrants.

A critical question courts ask to determine if the search was permissible is the whether the location information, acquired without a warrant, was private or

* Yuichiro Tsuji, Associate Professor of the Graduate School of Humanities and Social Science (legal major) at the University of Tsukuba; J.S.D University of California, Berkeley; LL.M. University of California, Berkeley; and Master of Law, Kyoto University.

1 Nihon-Koku Kenpō [Constitution of Japan] May 3, 1947 (Japan).

2 ibid. Art.31.

3 Keiji Sosho Hō [Code of Criminal Procedure], Act no. 131 of 1948 (Japan). 
public information. Accordingly, the purpose of this discussion is to review the distinction between the public and private spheres of our lives.

\section{Decisions from Japan and the U.S. on GPS warrantless investigation}

In 2017, the Japanese Supreme Court ${ }^{4}$ held a warrantless GPS search illegal. In that case, law enforcement, on suspicion of larceny, placed GPS devices on 19 cars for approximately 6 months without warrants. These cars belonged to the defendants, their friends, and acquaintances, none of whom had consented to an investigation. Police monitored, collected, and stored location information of the cars. The Osaka District Court ${ }^{5}$ found the GPS searches to be illegal and excluded the data acquired by the GPS investigation; however, the defendants were found guilty based on other evidence. The appellate court ${ }^{6}$ held that as the GPS investigation was compulsory action, it was illegal and required statutory authorization. Ultimately, the Japanese Supreme Court sustained the prior rulings, holding that the GPS investigation was not permissible without special legislation. Only under limited conditions set forth in Article $212^{7}$ of Criminal Procedure Act and Article $35(1)^{8}$ of Japanese Constitution are warrantless arrests permitted; those conditions required that the person to be arrested must be in the very act of committing or has just committed an offense as a flagrant offender. In this case, there were no such circumstances that would authorize the use of a warrantless search. ${ }^{9}$

Though the Japanese legal system is classified as a civil law country, while the U.S. system is classified as common law, the two countries' decisions on matters of warrantless GPS searches followed similar reasoning. In fact, the Japanese law enforcement may have applied the ruling from United States v. Jones in 2012.

In 2012, in United State v. Jones ${ }^{10}$, the U.S. Supreme Court held that under the Fourth Amendment of the U.S. Constitution ${ }^{11}$ warrantless searches via GPS investigation on public roads without consent of suspects are illegal. In that case, to support the conclusion that no warrant was necessary, law enforcement argued that there is no reasonable expectation of privacy on public streets. ${ }^{12}$ The U.S. Court explained that Katz v. U.S. ${ }^{13}$ changed the property right approach to the

4 GPS decision in Japan, supra note 1.

5 Osaka Chihō Saibansho [Osaka Dist. Ct.] July 10, 2015, Heisei 25(wa) no. 5962, 71(3)

Saikō Saibansho Keiji Hanreishu [Keishu] 164 (Japan).

6 Osaka Kotō Saibansho [Osaka High Ct.] March 2, 2016, Heisei 27(u) no. 966, 71(3) Saikō Saibansho Keiji Hanreishu [Keishu] 171 (Japan).

7 Keiji Sosho Hō [Code of Criminal Procedure], Art.212 (Japan).

8 Nihon-Koku Kenpō [Constitution of Japan] Art.35(1) (Japan).

9 GPS decision in Japan, supra note 1.

10 United States v. Jones.

11 The 4th amendment of the U.S. Constitution.

12 Jones, at $400,412$.

13 Katz v. United States, 389 U.S. 347 (1967). 
Fourth Amendment, in which the search-related protection was based on the property right in the invaded place, into an expectation of privacy standard. However, Alderman v. United States and Soldal v. Cook County ${ }^{14}$ maintained the trespass approach; thus, the expectation of privacy did not replace the trespass approach under common law. Writing the majority opinion, Justice Scalia ${ }^{15}$ explained it was necessary to focus on the meaning of the Fourth Amendment as adopted, holding that the trespass test works when no governmental interests exist.

Justice Sotomayor ${ }^{16}$, writing the concurring opinion, offered an interpretation that is familiar to Japanese law scholars. She emphasized that

[p] eople disclose the phone numbers that they dial or text to their cellular providers; the URLS that they visit and the e-mail addresses with which they correspond to their Internet service providers; and the books, groceries, and medications they purchase to online retailers... I for one doubt that people would accept without complaint the warrantless disclosure to the Government of a list of every Web site they had visited in the last week, or month, or year. But whatever the societal expectations, they can attain constitutionally protected status only if our Fourth Amendment jurisprudence ceases to treat secrecy as a prerequisite for privacy. I would not assume that all information voluntarily disclosed to some member of the public for a limited purpose is, for that reason alone, disentitled to Fourth Amendment protection.

By supporting trespassory invasion by law enforcement, Sotomayor highlighted that violation of the Fourth Amendment occurs when the expectation of privacy is infringed upon as well by non-physical intrusion. Moreover, she noted $^{17}$ that [a]wareness that the Government may be watching chills associational and expressive freedoms. And the Government's unrestrained power to assemble data that reveal private aspects of identity is susceptible to abuse. The net result is that GPS monitoring-by making available at a relatively low cost such a substantial quantum of intimate information about any person whom the Government, in its unfettered discretion, chooses to track may 'alter the relationship between citizen and government in a way that is inimical to democratic society.'

In a concurring opinion, Justice Alito ${ }^{18}$ doubted the majority opinion, stating that "asked of late 18th century situations that are analogous to what took place in this case... [P] hysical intrusion is now unnecessary to many forms of surveillance[.]" He also observed that "longer term GPS monitoring in investigations of most offenses impinges on expectations of privacy." Pointedly, Alito stated that one role of the judiciary is to restrict unfettered governmental activity: ${ }^{19}$ If

14 Alderman v. United States and Soldal v. Cook County, 506 U.S. 56 (1992).

15 Jones, at 405.

16 ibid. at 417 (Sotomayor, J., concurring).

17 ibid. at 416.

18 ibid. at 414 (Alito, J., concurring).

19 ibid. at 425 . 
long-term monitoring can be accomplished without committing a technical trespass-suppose, for example, that the Federal Government required or persuaded auto manufacturers to include a GPS tracking device in every car-the Court's theory would provide no protection.

As for Japan's consideration of this constitutional question, Prof. Lawrence Repeta $^{20}$ described that the Japanese Supreme Court's ultimate decision was rare, given that the number of decisions holding some governmental action unconstitutional since the promulgation of the current constitution was established. ${ }^{21}$

\section{Japanese GPS decision}

Before comparing the Japanese decision with the Jones decision in Chapter III, it is necessary to provide an overview of Japanese police investigations. In Japan, investigation by law enforcement is divided into two types: investigation with consent and investigation without consent, which is referred to as a compulsory measure (disposition) ${ }^{22}$ such as search and seizure. Compulsory measures, as defined by the Japanese Supreme Court ${ }^{23}$, are governmental actions that infringe on constitutionally important interests by suppressing individual wills; thus, the legislature must pass statutes authorizing such compulsory measures. Other actions that are not compulsory measures fall under the investigation with consent category. Under Articles 33 and $35^{24}$ of the Japanese Constitution, compulsory measures obligate law enforcement to receive judicial warrants that are regulated by the Criminal Procedure Act. Under this $\mathrm{Act}^{25}$, the warrant requires a clear statement of purpose and specificity of items to be searched for and places to be searched.

In the Japanese GPS decision ${ }^{26}$, law enforcement argued that the GPS investigation did not require a judicial warrant because it did not lead to a serious infringement of privacy, and, as the investigation was similar to instances when suspects run away, the same policy should be applied. This argument was based on the Japanese National Police Agency's (NPA) guidelines ${ }^{27}$, issued in 2006 to

20 Prof. Lawrence Repeta translated this term into "compulsory action". REPETA, Lawrence, Japan Supreme Court Limits Police GPS Surveillance Citing Constitution Article 35, Blog of the International Journal of Constitutional Law (17. August, 2017). [Online]. Available at: < http://www.iconnectblog.com/2017/08/japan-supreme-court-limits-police-gpssurveillance-citing-constitution-article-35/ > Accessed: 10. March, 2018.

21 TSUJI, Yuichiro, Constitutional Law Court in Japan, 2016, vol. 66, Tsukuba Journal of Law and Politics, pp. 65, 68, 73-75.

22 Keiji Sosho Hō [Code of Criminal Procedure], Art.197(1) (Japan).

23 Saikō Saibansho [Supreme Court] March 16, 1976, Showa 50 (a) no. 146, 30(2) Saikō Saibansho Keiji Hanreishu [Keishu] 187 (Japan).

24 Nihon-Koku Kenpō [Constitution of Japan] Art. 33, 35 (Japan).

25 Keiji Sosho Hō [Code of Criminal Procedure] Art. 218 (Japan).

26 GPS decision in Japan, supra note 1.

27 The Nikkei Shimbun, GPS Sousa Hanzai 7 Ruikeini-Keisatucho ga 06 nen ni Unnoyo kitei - [The NPS guideline for operation of GPS investigation for 7 types of cases in 2006]. 
all prefectures' police departments, which did not regard GPS investigation as a compulsory measure. These guidelines permit the use of GPS investigation only when (1) no other investigation method is available and (2) the investigation involves a serious crime such as kidnapping, robbery, or theft. One law enforcement office remarked that GPS was often the only investigation method available because, to evade police, criminals will speed in their cars, change their car license plates, and use divergent maneuvers, which make helicopter chases difficult. Moreover, in some cases, criminals leave no DNA evidence by wearing masks and gloves.

Rejecting the government's arguments, the Japanese Supreme Court ${ }^{28}$ held that GPS investigation was a compulsory measure; thus, its use required legislation. Concurring opinions by Justices Kiyoko Okabe, Takehiko Ohtani, and Masayuki Ikegami ${ }^{29}$ stated that GPS investigations should be allowed under strict conditions while the legislature prepares a bill on GPS investigation.

Before this decision was rendered by the Japanese Supreme Court in 2017, the Osaka High Court ${ }^{30}$ left some room for warrantless GPS search under two conditions: when (1) the GPS investigation meets the existing requirement of inspection under Article $218^{31}$ and expert examination under $225^{32}$ of Criminal Procedure Act and (2) the judge reviews the warrant narrowly and strictly. The Japanese Supreme Court did not endorse this holding; instead, it emphasized that GPS investigation is different from existing inspection and expert examination in nature, and explained that compulsory measures require legislative justification to pass a statute in the Diet. Individual judges cannot avoid this process if GPS was presumed to be other than the existing compulsory measure. Thus, it seems that Japanese Supreme Court determined that judges may not issue warrants for investigations that were not clearly authorized in the Diet. This reasoning is similar to one in U.S. v. Jones decision of the United States.

Soon after this decision, the NPA issued a notice ${ }^{33}$ to prefecture police departments advising that investigations should refrain from using GPS devices. As is true in the U.S., in Japan, law enforcement may conduct searches, seizures,

(15. February, 2017).[Online].Available at: < https://www.nikkei.com/article/DGXLASDG15H0Q_V10C17A2CC0000/ > Accessed: 1. March, 2018.

Japanese Bar Association protested. JBA, GPS Idou Tsuiseki Souchi wo mochiita Ichi Jouhou tansak sousa ni kansuru Ikensho [Protest against GPS device investigation] (19. January, 2017).[Online]. Available at: https://www.nichibenren.or.jp/library/ja/opinion/report/data/2017/opinion_170119_03.pdf Accessed: 1. March, 2018.

28 GPS decision in Japan, supra note 1.

29 Okabe, Ohtani and Ikegami, J., concurring.

30 Osaka High Ct., supra note 8.

31 Keiji Sosho Hō [Code of Criminal Procedure] Art.218 (Japan).

32 ibid. Art. 225.

33 The Nikkei Shimbun, Keisatucho Zenkoku ni Chusi Tsutatu [NPA orders no use of GPS] (16. March, 2017).[Online]. Available at:< https://www.nikkei.com/article/DGKKZO14131280W7A310C1EA1000/> Accessed: 1. March, 2018. 
and warrantless arrests of persons who are in the very act of committing or have just committed an offense as flagrant offenders under Article $35^{34}$ of Japanese Constitution. Thus, Japanese police can avoid two required judicial warrants for search and arrest when confronted with flagrant offenders. However, in the GPS case, there was no such extenuating circumstance to make the warrantless search legal.

Compared to U.S. legal precedent, the Japanese judiciary emphasized the necessity of investigation so much that law enforcement expects the Japanese courts to expand the requirements of inspection and special expert examination for new investigations. These unique circumstances help explain why the Osaka high court decision ${ }^{35}$ left some room for warrantless GPS investigation in the future. For instance, after this decision was rendered in March 2017, one prefecture police lieutenant installed a GPS device on a car belonging to a Japanese gang member (Yakuza) without a warrant just a month later. ${ }^{36}$ Another prefecture police officer arrested the individual on a different charge, and an acquaintance of the defendant submitted this GPS device. In response, the prefecture police department disciplined the lieutenant via a pay cut and apologized for the illegal use of the GPS device.

Overall, it appears that the 2017 Japanese GPS decision may have followed the ruling set forth in U.S v. Jones, stressing the constitutional muster for the judicial and legislative requirements under Article 35 of Japanese Constitution.

\section{Comparison between Japan and the U.S.}

As explained above, GPS investigations are illegal unless permitted by statute. When using the comparative law approach, we should be vigilant in examining the different legal systems used by the U.S. and Japan. The Japanese police system is similar to the U.S. system because of the influence of the General Headquarter (GHQ) occupation following World War $\mathrm{II}^{37}$, which led the country to model its law enforcement rules in the 1950s based on U.S. law, modifying the law and polices when necessary to fit with Japanese society.

For example, in 1954, the Japanese prime minister submitted a bill to amend the Police Act to reorganize the police system. Before this revision, police organi-

34 Nihon-Koku Kenpō [Constitution of Japan] Art. 35 (Japan).

35 Osaka Kotō Saibansho [Osaka High Ct.] March 2, 2016, Heisei 27(u) no. 966, 71(3) Saikō Saibansho Keiji Hanreishu [Keishu] 171 (Japan).

36 The Mainichi Shimbun, Reijo nasi de GPS Sousa[Warrantless GPS search](12, Dec., 2017). Available at: $<$ https://mainichi.jp/articles/20171227/k00/00m/040/124000c > Accessed: 1. March. 2018.

37 TSUJI, Yuichiro, Article 9 and the History of Japan's Judiciary: Examining Its Likeness to American and German Courts, Tsukuba Journal of Law and Politics, 2016, vol. 66, pp. 36-40. 
zation followed GHQ advice and established municipalities. ${ }^{38}$ The police discovered that this organizational strategy was too expensive and did not effectively manage cross border crimes; moreover, human resources overlapped with the central police. Thus, the revised Police Act of $1954^{39}$ centralized the power of central police, the NPA, while local police managed at the prefecture level, not municipality level.

In 1958, Prime Minister Nobusuke Kishi amended the Police Duties Execution Act to expand the power of law enforcement. ${ }^{40} \mathrm{He}$ tried to submit an amendment to add not only the protection of individual's property rights, safety, and life but also the protection of public order. The history of this legislative process shows that the legislature responded to amend the statutes when it recognized their limitations and problems. ${ }^{41}$

Today, Chapter 8 of the Japanese Constitution ${ }^{42}$ provides local governments with autonomy; however, the autonomy does not conform to the U.S. federalism model. Although there are local government ordinances that are similar to state law in the U.S., no prefectural court exists in Japan.

Just as the Federal Bureau of Investigation in the U.S. controls crime beyond state borders, the NPA controls and coordinates local police departments. As the Jones decision suggests, a warrant must specify the location to be searched, the significance of crime, and the nature and length of the investigation. Problems may arise when suspects go beyond the geographic limitation specified in warrant. In both the U.S. and Japanese cases, law enforcement asked the Supreme Courts to set limitations on warrantless search. Accordingly, both courts set limitations on the excessive investigation of law enforcement.

\subsection{Uniqueness of Japanese criminal law}

Before WWII, the Japanese Criminal Procedure Act was adapted from German law, but following the war, Japan adapted its criminal procedure to conform to U.S. law. However, unlike U.S. common law, Japanese courts allow law enforcement to expand the existing requirement to unwritten investigation. If law enforcement collects a blood sample, which was not permitted by law, the Japanese Supreme Court will request both a physical examination warrant and expert examination. In carrying out forced urine collection from a suspect, the

38 NPA, Keiji Keisatshu no Rekisi[ History of police ] (2008).[Online]. Available at: $<$ https:// www.npa.go.jp/hakusyo/h20/honbun/html/kd100000.html > Accessed: 1. March. 2018.

39 Keisatsu Hō [The Police Act], Act No. 162 of 1954 (Japan).

40 The Mainichi Shimbun, Showa Mainich [Daily lives in Showa era] (8. June, 1954). [Online]. Available at: < http://showa.mainichi.jp/news/1954/06/post-81ac.html> Accessed: 1. March, 2018.

41 TSUJI, Yuichiro, Forgotten People: A Judicial Apology for Leprosy Patients in Japan, 2018, Or. Rev. Int'l. L., vol. 19, pp. 238.

42 Nihon-Koku Kenpō [Constitution of Japan] Chapter 8 (Japan). 
Japanese Supreme Court ${ }^{43}$ held that a search and seizure warrant was required. The reason judicial warrants are required was stipulated in Article $172^{44}$ for compulsory measure and expert investigation under Article 225(4) ${ }^{45}$ of Criminal Procedure Act. Although Article $172^{46}$ allows exceptional compulsory investigation, expert investigation under Article 225 (4) has no exception to compulsory investigation when a suspect did not consent. Thus, the Japanese Supreme Court requested an additional judicial warrant of physical examination under Articles 218(1), 222, and 139. ${ }^{47}$ This exception for unwritten investigation established by the Japanese Supreme Court is uniquely broad.

Japanese law professors have analyzed, developing two theories as to how unwritten investigations are handled. First, it is possible that an unwritten investigation is prohibited ${ }^{48}$ unless the legislature passes or amends the Criminal Procedure Act. It is reasonable to believe that forced urine collection causes emotional and physical damage and infringes on human dignity so severely that it is not allowed without specific legislation.

Second, if unwritten investigation is allowed under strict requirements, this is because the judiciary put law enforcement under restrictions like the judicial warrant of physical or expert examination. ${ }^{49}$ If collecting urine is the last resort in evidence collection, an emergency could authorize forced urine collection even though certain physical examinations under Article $218^{50}$ of Criminal Procedure Act cause similar humiliation. In situations without extenuating circumstances, the suspect should submit urine voluntarily and a doctor or professional technician should carefully collect the sample.

In 1980, the Japanese Supreme Court ${ }^{51}$ requested a judicial warrant of search and seizure for forced urine collection because urine collected from the body of a suspect is similar to evidence collected by warrants of search and seizure. The judiciary required compelling interest of investigation and stated that it can only be used as a last resort after reviewing the significance of the case, the existence

43 Saikō Saibansho [Supreme Court] Oct. 23, 1980, Showa 54 (a) no. 429, 34(5) Saikō Saibansho Keiji Hanreishu [Keishu] 300 (Japan).

44 Keiji Sosho Hō [Code of Criminal Procedure] Art.172 (Japan).

45 ibid. Art 225(4).

46 ibid. Art 172.

47 ibid. Art 218(1), 222, 139.

48 TAKIZAWA, Makoto, GPS wo mochiita higisha no shozai bashono kensaku ni tsuite [Searching location of suspect via GPS], MEMORIAL OF SEVENTY YEARS OLD OF PROF. NIROKU TATEISHI. Japan: Seibundo, 2010, pp. 730. KAMIGUCHI, Yutaka, KEIJI SOSHO HO [Criminal procedure Act, 3rd edition]. Japan: Seibundo, 2012, pp. 6.

49 IBUSUKI, Makoto, Haitecku kiki wo riyou sita tsuibi kanshi gata souse [Monitoring investigation via high technology], MEORIAL OF PROF.SHIGETSUGU SUZUKI, VOL.2. Japan: Seibundo, 2007, pp. 182.

50 Keiji Sosho Hō [Code of Criminal Procedure] Art. 172 (Japan).

51 Saikō Saibansho [Supreme Court] Oct. 23, 1980, Showa 54 (a) no. 429, 34(5) Saikō Saibansho Keiji Hanreishu [Keishu] 300 (Japan). 
of suspicion, the importance and necessity of evidence, and the (un)availability of alternative methods. The judiciary demanded law enforcement to write the specific condition on the search and seizure warrant, including the appropriate medical method and that only a medical doctor could conduct the collection.

In this case, law enforcement requested a judicial warrant for illegal drug trafficking and arrested the defendant at 10:00 am on June 28, 1977. After the arrest, law enforcement requested the defendant voluntary submit a urine sample to test for the use of illegal drugs, but the defendant refused. Therefore, the law enforcement requested expert examination and physical examination under Article $218^{52}$ of Criminal Procedure Act, and judicial warrants were issued at 4:00 pm on June 29th. Evidence acquired by catheter showed that the suspect's urine contained illegal drugs. The defendant argued that it was illegal evidence and should therefore be excluded from the government's attempt to convict him of illegal drug possession.

In 1980, the Japanese Supreme Court upheld the validity of the warrant of physical and expert examination in this case. Japanese scholars criticized this decision, arguing that the targets of "search and seizure" are material substances, not fluids in the body. Ergo, the scholars found the use of the search and seizure warrant illegal in this case. Law enforcement may have followed the holding in this case in their actions that resulted in the 2017 GPS decision.

\subsection{Wiretapping in Japan}

As noted, the U.S. is a common law jurisdiction, while Japan is a civil law jurisdiction. As the Jones decision illustrates, in the U.S., the judiciary is required to rule consistently with prior decisions, like the Katz ${ }^{53}$ decision, and is merely allowed to set limitations on the scope of the prior decisions. Although not a common law jurisdiction, Japan's Supreme Court must also decide cases based on precedent. However, the way courts cite precedent in their reasoning is so convoluted that Japanese scholars struggle to find consistency among decisions.

Nonetheless, today, the differences between the judicial systems in the U.S. and Japan are relatively small. In the U.S., wiretapping is permissible through special legislation that gave such power to law enforcement. Before the legislation, the use of wiretapping by law enforcement was challenged in the U.S. Supreme Court. ${ }^{54}$ Similar to the 2017 decision, law enforcement brought sued the court to determine the boundary of legal investigation. This kind of determination is applied to the Jones case. ${ }^{55}$

52 Keiji Sosho Hō [Code of Criminal Procedure] Art.218 (Japan).

53 Katz.

54 ibid.

55 Jones. 
In a wiretapping investigation case, the Japanese Supreme Court ${ }^{56}$ held that wiretapping investigation was compulsory procedure that should be set by the legislature. The Court left some exception for wiretapping, as it was, at that time, not legal in the Diet. Limited circumstances permitted the use of wiretapping, including the significant nature of crime, sufficient reason to believe that a suspect will commit a crime, probable cause that a conversation would be carried out for suspected fact, the unavailability of alternative methods to acquire vital evidence, and the balancing of the human right violated by the wiretapping with the purpose of investigation. ${ }^{57}$ The Court noted that only a compelling interest would make wiretapping legal under due process of law before it was legalized in the Diet.

Justice Toshifumi Mothara wrote the dissenting opinion ${ }^{58}$, arguing that wiretapping was a compulsory procedure that requires a statute; thus, the evidence should have been excluded. His dissenting opinion relates to the GPS deci$\operatorname{sion}^{59}$ in Japan as he warned that conversation acquired by wiretapping inevitably includes non-criminal conversation. Law enforcement must select only the necessary conversation to submit as evidence. Thus, because the scope of the inspection warrant covers only criminal conversation, its use for wiretapping goes beyond the interpretation of law that the judiciary is expected to exercise.

In this case, the Japanese Supreme Court explained that when the legislature provides procedure for wiretapping, law enforcement may use other existing procedure such as physical examination under Article $218^{60}$ of Criminal Procedure Act. In 1999, the Diet passed the Act on Wiretapping for Criminal Investigation. ${ }^{61}$ This wiretapping decision is related to analysis of GPS decision. ${ }^{62}$

\subsection{Exclusionary rule in Japan}

The compulsory disposition rule is connected to the exclusionary rule. Not only provisions, Japanese law scholars continuingly reviewed the U.S. case law regarding to criminal law procedure law and considered if doctrines noted in the United States Supreme Court practically work in Japan. The Japanese Supreme Court changed the imported U.S. legal principles slightly. It is interesting to see how the U.S. legal principle led to certain unique characteristics of Japanese law.

56 Saikō Saibansho [Supreme Court] Dec. 16, 1999, Heisei 9 (a) no. 636, 34(5) Saikō Saibansho Keiji Hanreishu [Keishu] 1327 (Japan).

57 ibid.

58 ibid. (Motohara, J., dissenting).

59 GPS decision in Japan, supra note 1.

60 Keiji Sosho Hō [Code of Criminal Procedure] Art.218 (Japan).

61 Hanzai Sousa no tameno Tsushin bouju ni kansuru Ho [Act on Wiretapping for Criminal Investigation], Law no. 137 of 1999. (Japan).

62 The Mainichi Shimbun, Court battles over warrantless GPS tracking of crime suspects show need for new law (3. March, 2016). [Online]. Available at: $<$ https://mainichi.jp/english/articles/20160303/p2a/00m/0na/001000c > Accessed: 1. March, 2018. 
One of unique characteristics is the exclusionary rule. Japan's exclusionary rule is not as strong as the rule in U.S. law. The first time the Japanese Supreme Court $^{63}$ was confronted with the exclusionary rule was in 1978. Prior to this case, the judiciary ${ }^{64}$ admitted evidence unconditionally because it opined that neither the form nor nature of acquired evidence was changed by being "illegal evidence." In the 1978 case $^{65}$, the law enforcement had interrogated defendants in a crime infested area. Two policemen suspected a defendant of being a drug addict and requested voluntary submission of his possessions. After he refused, they frisked the pockets of his jacket and trousers. They noticed something solid, though not a knife, and reached into his pocket and found drugs. The Japanese Supreme Court stated that frisking in an interrogation requires the suspect's consent, however, police may frisk without triggering the consent requirement under certain circumstances: necessity, emergency, and by balancing the infringed right and the protection of public welfare. The Japanese Supreme Court ${ }^{66}$ permitted the introduction of this evidence because requirements of interrogation were satisfied and, although the suspect did not consent, the police had no intent to avoid the procurement of a judicial warrant, and the illegality of police action was slight.

Four years before this Japanese Supreme Court decision, the U.S. Supreme Court allowed stop and frisk in Terry vs. Ohio ${ }^{67}$ under the Fourth Amendment when law enforcement had a reasonable suspicion that the suspect was about to commit a crime. The Japanese judiciary may have followed principles that emerged in that U.S. decision.

After the U.S. Supreme Court set forth a limitation on a state court decision in Wolf v. Colorado ${ }^{68}$, it applied the exclusionary rule in Mapp v. Ohio ${ }^{69}$ under the Fourth Amendment. As explained above, Japan does not have a state court system; however, based on the ruling in the 1978 decision, it appears that the Japanese Supreme Court may have applied the principles of Wolf and Mapp.

Compared with the U.S. decisions, the Japanese cases demonstrate that compulsory disposition was not as strongly linked to the exclusionary rule as it was in the U.S. Just as the wiretapping decision in Japan sustained the defendant's guilt, the frisk decision in 1978 opted not to exclude the evidence. Similarly, the

63 Saikō Saibansho [Supreme Court] Sep. 7, 1978, Showa 51 (a) no. 865, 32(6) Saikō Saibansho Keiji Hanreishu [Keishu] 1672 (Japan).

64 Saikō Saibansho [Supreme Court] Dec. 13, 1949, Showa 24 (re) no. 2366, 15 Saikō Saibansho Keiji Hanreishu [Keishu] 349 (Japan).

65 Saikō Saibansho [Supreme Court] Sep. 7, 1978, Showa 51 (a) no. 865, 32(6) Saikō Saibansho Keiji Hanreishu [Keishu] 1672 (Japan).

66 ibid.

67 Terry vs. Ohio, 392 U.S. 1 (1968).

68 Wolf v. Colorado, 338 U.S. 25 (1949).

69 Mapp v. Ohio, 367 U.S. 643 (1961). 
compulsory urine collection decision sustained the legality of the forced urine collection.

Based on these decisions, law enforcement in Japan is likely to think that data acquired by GPS device may be permissible as supporting evidence and could, at a minimum, influence the judges' decision unless Japan strictly applied the exclusionary rule as did the U.S. in its 2017 GPS decision as such a decision may have placed the Japanese law enforcement's action through the due process of law analysis. The 2017 GPS decision encouraged the Japanese legislature to pass a new statute on GPS investigation. In both of the U.S. and Japanese decisions, the judiciaries encouraged the legislatures to pass statutes on the matter, though they did not provide clear details about such legislation. ${ }^{70}$

Law enforcement may engage in impermissible and unlawful investigation to uncover evidence in case; for example, they may forego the judicial warrant process in order to avoid the limitations the warrants establish. In Japanese cases, the exclusionary rule may not effectively set limits on illegal investigation; in fact, it may be so ineffective that it could been referred to as a toothless rule $^{71}$, even though it was adopted from the same legal doctrine as applied in the U.S. Accordingly, though Japan and the U.S. apply similar reasoning behind the exclusionary rule, it is clear that the application of the rule results in different outcomes in the two countries.

Similar to the U.S. Court, the Japanese Court recognizes that the purpose of compulsory disposition is to reign in arbitrary investigation. Japanese courts set conditions and limitations on the exclusionary rule to uphold the determination of a defendant's guilt. Thus, Japanese law enforcement may tend to submit illegal evidence into the record to influence the judge's decision-making process even though the evidence may ultimately be excluded. This tendency is supported by the Japanese Supreme Court's decisions to exclude illegal evidence, while simultaneously upholding guilty verdicts.

\section{Constitutional Analysis of GPS investigation}

\subsection{Response of the legislature}

The Japanese Supreme Court and the U.S. Supreme Court play two roles. Although the Japanese Constitution does not create a federalist system like the U.S. Constitution, both Constitutions uphold the supremacy of law that requires Supreme Courts to uniformly interpret law through their decisions when conflicts arise with inferior court decisions. Neither Supreme Court is permitted to

70 TSUJI, Yuichiro, Forgotten People: A Judicial Apology for Leprosy Patients in Japan, 2018, Or. Rev. Int'l. L., vol. 19, pp. 223. (It analyzes independence of judges in cases against the government).

71 MORITA, Chihokota, Case review of GPS Supreme Court Decision, Tsukuba Journal of Law and Politics, 2018, vol. 73, pp. 21-37. 
rewrite statutory language; however, they may encourage their respective law making organs to enact laws when the cases before them demonstrate the need to create a legal ground through which investigation via new technology can be regulated. As Justice Alito $^{72}$ in the Jones decision illustrates, new investigations via innovative technologies may exceed the original intent of the legislature with respect to investigations. Ergo, given that the Japanese legislature is now aware of new technological advances, it has determined that location privacy will be encompassed within privacy protection.

In 2013, the Ministry of Internal Affairs and Communications (MIC) ${ }^{73}$ established that the character of privacy in location data increases in strength as the data becomes more precise and sets of data become sequences. Then in 2015 , the $\mathrm{MIC}^{74}$ abolished the obligation of telecommunication carriers to notify users that they are collecting location data. It seems that this change encouraged the use of GPS devices for investigations. It is notable that the policies surrounding these issues are only guidelines, not statutes passed by Parliament. ${ }^{75}$ These guidelines reveal that the legislature believes that location data comprises privacy. The uniqueness of Japanese law enforcement management is that the Ministry of Justice manages law enforcement by ministerial guidelines, not statutes. ${ }^{76}$ It is no wonder that law enforcement believe that it will take a long time to pass a statute legalizing GPS investigation if the decision-making ability of the Diet or Congress is hampered by other political scandal. In Japan, law enforcement tends to depend on administrative regulations, ministerial ordinances, or guidelines that avoid the political process in the parliament. The MIC provided guidelines for protection of privacy in the telecommunications business.

After the 2017 decision, one politician asked the Ministry of Justice how many times law enforcement asked telecommunication businesses to acquire GPS information under the MIC guidelines. The government answered that it was not clear. In this same conversation, in 2017, the politician asked another question regarding how continuously GPS data is required. The politician clarified that because one-time data is not helpful for locating suspects, law enforcement must need sequences of location data. The government answered that the question was unclear, saying that it believed that law enforcement acquiring location data must have received judicial warrants. In addition, the government

72 Jones, at 420 (Alito, J., concurring).

73 MIC, Denki Tsushin Jigyou ni okeru Kojin Jouhou hogo ni kansuru gaido rain [Guideline for telecommunication for protection of privacy](March, 2015). [Online].Available at: <http://www.soumu.go.jp/main_sosiki/joho_tsusin/d_syohi/telecom_perinfo_guideline_intro.html > Accessed: 1. March. 2018.

74 ibid.

75 TSUJI, Yuichiro, Medical Privacy Issues in Ageing Japan, Australian Journal of Asian Law, 2017, vol. 18, No. 1, article 6, pp. 7-8.

76 The House of Representatives of Japan, Question by Member of House of Representatives Takeshi Shina (7, December, 2017). [Online]. Available at:< http://www.shugiin.go.jp/ Internet/itdb_shitsumon.nsf/html/shitsumon/a195022.htm >Accessed: 1. March, 2017. 
noted in the committee that law enforcement didn't send notice to the target that it made GPS investigation.

\subsection{Constitutional barrier, privacy doctrine}

A constitutional right to privacy may work to block the use of illegal investigations in court. ${ }^{77}$ The Court offered some suggestions to the legislature about such a right, but did not provide any specific steps on how to legislate. There is no express term for privacy in the Japanese Constitution or the U.S. Constitution. In the U.S., privacy is likely a product of common law, while in Japan the term privacy, having not been clearly written, was later mentioned in judicial decisions. ${ }^{78}$ Reviewing the U.S.'s winding path of common law, Japanese law scholars have explained the importation of U.S. laws in Japanese decisions. Accordingly, when examining the two countries' judicial review process, scholars find significant similarities.

Even though innovative technologies emerge, causing courts to question the statutory language and legislative intent, it seems that the value of human dignity does not change. ${ }^{79}$ Privacy was a product of battles between the judicial, legislative, and executive branches that were vested with power by the Constitution. In Japan, the concept of privacy emerged in 1970-possessing a relatively short history compared with other constitutional rights such as the right to property. In GPS cases in both the U.S. and Japan, privacy has been further analyzed to parse out limitations on government encroachment and individual's rights.

As the concurring opinions of Justice Sotomayor, Justice Alito, Professor Tsuyoshi Hiramatsu ${ }^{80}$ shows that privacy is closely connected with human autonomy and dignity. Hiramatsu argued that the Japanese Constitution protects the right to information privacy. Today, the foresight of constitutional scholars has been realized. Our daily activities are monitored, collected, and rearranged in computer databases in ways that often shape our experiences without our consent. Vast quantities of information are rapidly transferred to third parties and stored forever in readily accessible formats, in stark contrast to earlier times when information might easily be forgotten or lost, whether stored in human memory or in hard copy. In such an environment, citizens who are concerned about being

77 TSUJI, Yuichiro, Medical Privacy Issues in Ageing Japan, Australian Journal of Asian Law, Law, 2017, vol. 18, No. 1, article 6. pp. 2-3.

78 ibid.

79 Laurence Tribe, The Constitution in Cyberspace (1999).[Online].Available at:<http:// groups.csail.mit.edu/mac/classes/6.805/articles/tribe-constitution.txt>

80 HIRAMATSU, Tsuyoshi, KOJIN JOUHUO HOGO [Protection of personal information] Japan: Gyosei,1999, pp. 47, 108, 195.

Koops, Bert-Jaap and Newell, Bryce Clayton and Škorvánek, Ivan, Location Tracking by Police: New Frameworks for Preserving Geolocational Privacy (February 12, 2018). UC Irvine Law Review, Vol. 9, Spring 2019, Forthcoming; Tilburg Law School Research Paper No. 2018-8. It explains that technology increases "discomfort" under classic privacy theories. 
watched or monitored by government become understandably inhibited, protective, or even defensive in their efforts to safeguard their personal privacy. Such results arguably infringe upon a liberty "protected by the Constitution." ${ }^{81}$

In the U.S., privacy is a product of common law, which was unable to set general limitations based on individual decisions. The judiciary cannot mandate the legislature to pass or abolish specific statutes; however, it can give the legislature some suggestions as to what policies may be necessary and viable. In Japan, the general public may focus on information privacy and pay less attention to autonomy, demonstrating how the right to privacy highlights different perspectives among various people. Constitutions are one of tools to coordinate competing perspectives and the powers vested to each governmental branch. People tend to follow other people's behavior blindly, avoiding questions related to different ideas on life and fearing unaccepted perspectives. Japanese law scholars are obligated to mention in Japan that privacy is rooted in autonomy-that humans may choose their own way of life-honing in on the uniqueness of human dignity and the fact that humans should not be forced to share the same ideas. If we feel that we are monitored by government, we may hesitate to be different. Based on the privacyrelated decisions in the GPS cases in the U.S. and Japan, it is clear that people will continue to demand privacy. It is not easy to predict the future, but one can imagine that privacy will remain one of the high barriers against illegal investigation, requiring legal scholars to examine where its limitation should be set.

Individuals may choose how they live in private sphere, and constitution works in conflict between comparing perspectives. The Constitution vests power to each branch of government to coordinate the public life of individuals. Although it is reasonable to state that when an individual is on public road, he or she waives privacy because of his or her location, neither the Japanese nor U.S. Supreme Court applied this reasoning. It seems that the boundary between the private and public sphere is clarified by the legislature, executive branch, and judiciary. Innovative investigation via new technology leads them to consider where to set its boundary. When given the opportunity to weigh in on the matter, the judiciary may work to protect a party in a case if the statute is imperfect or if law enforcement avoided its restriction by ministerial order or guideline.

For example, Professor Makoto Ibusuki ${ }^{82}$ described that the 2017 Japanese Supreme Court decision expanded the notion of private space to include entries to private areas. The 2017 GPS decision suggested that, if necessary, the legislature should pass a statute to address new types of investigation. Because privacy was originally a product of common law, it requires the judiciary to set limita-

81 ibid.

82 IBUSUKI, Makoto, Kanshi no Jidai to Puraibashi [The age of surveillance and privacy], Sekai, 2017, pp. 46-54.

IBUSUKI, Makoto, GPS SOUSA TO PURAIBASHI HOGO [GPS Investigation and protection of privacy].Japan: Gendai Jinbunsha, 2018. 
tions on privacy on a case-by-case basis. As a result, the scope of judicial decisions is so narrow that law enforcement tends to act within the blurred boundary of lawful investigation. ${ }^{83}$ Japanese law enforcement uses guidelines or ministerial ordinances to avoid legal limitations, while the Japanese Court extended the use of existing procedure to innovative investigation methods. The limited scope of judiciary decision may not be able to provide equality under the law or predictability. Due to the extended length of time required to enact new law, it seems that law enforcement will continue to push the boundaries of the narrow scope of judicial decisions.

Japanese law scholars are obligated to bridge the gap between the general public and legal professions, and to reveal that imported U.S. doctrines, having been adapted and applied in Japan, have sometimes led to opposite conclusions even when the two countries took similar approaches. We should be vigilant that legal doctrine in the U.S. become name only in Japan by Japanese judiciary.

\section{Conclusion}

One of unique characteristics of criminal procedure is the exclusionary rule. Japan's exclusionary rule is not as strong as the rule in U.S. law. In Japan, compulsory disposition was not as strongly linked to the exclusionary rule as it was in the U.S.

Thus, Japanese law enforcement may tend to submit illegal evidence into the record to influence the judge's decision-making process even though the evidence may ultimately be excluded. This tendency is supported by the Japanese Supreme Court's decisions to exclude illegal evidence, while simultaneously upholding guilty verdicts.

Based on this exclusionary rule, law enforcement in Japan is likely to think that data acquired by GPS device may be permissible as supporting evidence and could, at a minimum, influence the judges' decision unless Japan strictly applied the exclusionary rule as did the U.S.

In Japan under concrete judicial review, the judiciary cannot obligate the legislature to pass or abolish specific statutes. Law making power is designated only to the Diet; however, it can give the legislature some suggestions as to what policies may be necessary and viable. In Japan, the general public may focus on information privacy and pay less attention to autonomy, demonstrating how the right to privacy highlights different perspectives among various people.

Constitutions are one of tools to coordinate competing perspectives and the powers vested to each governmental branch. People tend to follow other people's

83 Prof. Repeta argues that Japanese court has not established clear precedent to guide police for requirement of warrant. supra note 22, Japan Supreme Court Limits Police GPS Surveillance, Citing Constitution Article 35. 
behavior blindly, avoiding questions related to different ideas on life and fearing unaccepted perspectives. Japanese law scholars are obligated to mention in Japan that privacy is rooted in autonomy.

Based on the privacy-related decisions in the GPS cases in the U.S. and Japan, it is clear that people will continue to demand privacy. It is not easy to predict the future, but one can imagine that privacy will remain one of the high barriers against illegal investigation, requiring legal scholars to examine where its limitation should be set.

Japanese law scholars are obligated to bridge the gap between the general public and legal professions, and to reveal that imported U.S. doctrines, having been adapted and applied in Japan, have sometimes led to opposite conclusions even when the two countries took similar approaches. We should be vigilant that legal doctrine in the U.S. become name only in Japan by Japanese judiciary.

\section{References}

Alderman v. United States and Soldal v. Cook County, 506 U.S. 56 (1992).

Fourth amendment of the U.S. Constitution.

Hanzai Sousa no tameno Tsushin bouju ni kansuru Ho [Act on Wiretapping for Criminal Investigation], Law no. 137 of 1999. (Japan).

HIRAMATSU,Tsuyoshi, KOJIN JOUHUO HOGO [Protection of personal information] Japan: Gyosei, 1999, pp. 47, 108, 195.

House of Representatives of Japan, Question by Member of House of Representatives Takeshi Shina (7. December, 2017).

IBUSUKI, Makoto, Kanshi no Jidai to Puraibashi [The age of surveillance and privacy], Sekai, 2017, pp. 46-54.

IBUSUKI,Makoto, GPS SOUSA TO PURAIBASHI HOGO[GPS Investigation and protection of privacy]. Japan: Gendai Jinbunsha, 2018.

IBUSUKI, Makoto, Haitecku kiki wo riyou sita tsuibi kanshi gata souse [Monitoring investigation via high technology], MEORIAL OF PROF.SHIGETSUGU SUZUKI, VOL.2. Japan: Seibundo, 2007, pp. 182.

JBA, GPS Idou Tsuiseki Souchi wo mochiita Ichi Jouhou tansak sousa ni kansuru Ikensho [Protest against GPS device investigation](19. January, 2017).

KAMIGUCHI,Yutaka, KEIJI SOSHO HO [Criminal procedure Act, 3rd edition]. Japan: Seibundo, 2012, pp. 6.

Katz v. United States, 389 U.S. 347 (1967).

Keiji Sosho HŌ [Code of Criminal Procedure] Law no. 131 of 1948, Art.172, 197(1), 212, 218, 222, 225 (Japan).

Keisatsu HŌ [The Police Act], Act No. 162 of 1954 (Japan).

Koops, Bert-Jaap and Newell, Bryce Clayton and Škorvánek, Ivan, Location Tracking by Police: New Frameworks for Preserving Geolocational Privacy (February 12, 2018). UC Irvine Law Review, Vol. 9, Spring 2019, Forthcoming; Tilburg Law School Research Paper No. 2018-8.

Laurence Tribe, The Constitution in Cyberspace (1999). 
Mainichi Shimbun, Court battles over warrantless GPS tracking of crime suspects show need for new law (3. March, 2016).

Mainichi Shimbun, Reijo nasi de GPS Sousa[Warrantless GPS search](12. Dec., 2017).

Mainichi Shimbun, Showa Mainich [Daily lives in Showa era] (8. June, 1954).

Mapp v. Ohio, 367 U.S. 643 (1961).

MIC, Denki Tsushin Jigyou ni okeru Kojin Jouhou hogo ni kansuru gaido rain [Guideline for telecommunication for protection of privacy](March, 2015).

MORITA, Chihokota, Case review of GPS Supreme Court Decision, TSUKUBA JOURNAL OF LAW AND POLITICS, 2018, vol. 73, pp. 21, 37.

NIHON-KOKU KENPŌ [Constitution of Japan] May 3, 1947, Art.31, 33, 35, Chapter 8 (Japan).

Nikkei Shimbun, GPS Sousa Hanzai 7 Ruikeini-Keisatucho ga 06 nen ni Unnoyo kitei - [The NPS guideline for operation of GPS investigation for 7 types of cases in 2006]. (15. February, 2017).

Nikkei Shimbun, Keisatucho Zenkoku ni Chusi Tsutatu [NPA orders no use of GPS] (16. March, 2017).

NPA, Keiji Keisatshu no Rekisi[ History of police ] (2008).

Osaka ChihŌ Saibansho [Osaka Dist. Ct.] July 10, 2015, Heisei 25(wa) no. 5962, 71(3) SaikŌ Saibansho Keiji Hanreishu [Keishu] 164 (Japan).

Osaka KotŌ Saibansho [Osaka High Ct.] March 2, 2016, Heisei 27(u) no. 966, 71(3) SaikŌ Saibansho Keiji Hanreishu [Keishu] 171 (Japan).

REPETA, Lawrence, Japan Supreme Court Limits Police GPS Surveillance Citing Constitution Article 35, Blog of the International Journal of Constitutional Law (17. August, 2017).

SaikŌ Saibansho [Supreme Court] Dec. 13, 1949, Showa 24 (re) no. 2366, 15 SaikŌ Saibansho Keiji Hanreishu [Keishu] 349 (Japan).

SaikŌ Saibansho [Supreme Court] March 16, 1976, Showa 50 (a) no. 146, 30(2) SaikŌ Saibansho Keiji Hanreishu [Keishu] 187 (Japan).

SaikŌ Saibansho [Supreme Court] Sep. 7, 1978, Showa 51 (a) no. 865, 32(6) SaikŌ Saibansho Keiji Hanreishu [Keishu] 1672 (Japan).

SaikŌ Saibansho [Supreme Court] Oct. 23, 1980, Showa 54 (a) no. 429, 34(5) SaikŌ Saibansho Keiji Hanreishu [Keishu] 300 (Japan).

SaikŌ Saibansho [Supreme Court] Dec. 16, 1999, Heisei 9 (a) no. 636, 34(5) SaikŌ Saibansho Keiji Hanreishu [Keishu] 1327 (Japan).

SaikŌ Saibansho [Supreme Court] March 15, 2017, Heisei 28 (a) no. 442, 71(3) SaikŌ Saibansho Keiji Hanreishu [Keishu] 13 (Japan).

TAKIZAWA, Makoto, GPS wo mochiita higisha no shozai bashono kensaku ni tsuite [Searching location of suspect via GPS], MEMORIAL OF SEVENTY YEARS OLD OF PROF. NIROKU TATEISHI. Japan: Seibundo, 2010, pp. 730.

Terry vs. Ohio, 392 U.S. 1 (1968).

TSUJI, Yuichiro, Article 9 and the History of Japan's Judiciary: Examining Its Likeness to American and German Courts, TSUKUBA JOURNAL OF LAW AND POLITICS, 2016, vol. 66, pp. 36-40.

TSUJI, Yuichiro, Constitutional Law Court in Japan, 2016, vol. 66, TSUKUBA JOURNAL OF LAW AND POLITICS, pp. 65, 68, 73-75. 
ICLR, 2018, Vol. 18, No. 1.

TSUJI, Yuichiro, Forgotten People: A Judicial Apology for Leprosy Patients in Japan, 2018, Or. Rev. Int'l. L., vol. 19, pp. 223, 238.

TSUJI, Yuichiro, Medical Privacy Issues in Ageing Japan, Australian Journal of Asian Law, 2017, vol. 18, No. 1, article 6, pp. 2-3, 7-8.

United States v. Jones, 565 U.S. 400 (2012).

Wolf v. Colorado, 338 U.S. 25 (1949). 